\title{
ANTIOXIDANT PROPERTIES OF DIFFERENT BLUEBERRIES SPECIES
}

\section{B. HRYVNAK, M. BARANOVSKY}

\author{
National Aviation University, Kyiv
}

Nowadays antioxidant properties of blueberries are widely used in medicine for drugs production and as additives to cosmetic products. Those fruits contain in composition different phenolic compounds, which eventually ensure their antioxidant properties. The number of blueberry plantations is increasing on the territory of Ukraine; therefore, the study of the antioxidant properties of various types of blueberry is particularly relevant. For recommendations on the production of commercial blueberries species, it is essential to determine the content of biologically active substances and evaluate their antioxidant activity of potentially useful parts of the plant.

Key words: blueberries, antioxidant, flavanols, anthocyanin, polyphenols, economy, ORAC, DPPH, free radicals.

The wide range of natural antioxidants found in fruits and vegetables helps our bodies protect against disease and age-related health risks. One of the commonly known antioxidant is blueberries species that contain in composition different phenolic compounds, which eventually ensure their antioxidant properties.

Wild blueberries are especially rich in anthocyanin, a flavonoid with potent antioxidant capacity. Highly concentrated in the deep-blue pigments of wild blueberries, anthocyanin is responsible for both color and powerful health protection potential.

New studies suggest the key to staying mentally sharp as you grow older may be as simple as including more blueberries in your daily diet. A rich source of 
disease-fighting antioxidants, blueberries have demonstrated a remarkable ability to reverse the effects of aging on the brain, helping to restore memory and cognition to a more youthful state.

Blueberries also appear to help ward off deadly cancers, while protecting cells against damage incurred by diabetes. Blueberries may even help prevent bothersome urinary tract infections.

Blueberry polyphenols help reduce inflammatory responses in essential brain cells, and could be potentially useful in modulating inflammatory conditions in the brain. Blueberries have been found to improve many of the changes in cognitive function that commonly occur with aging. For example, scientists believe blueberries help reverse age-related decline in nerve-cell signaling, preserving the cells' ability to communicate with each other over time.

The study found that a one-cup serving of wild blueberries had more antioxidant capacity than a comparable serving of cranberries, strawberries, plums, or raspberries. Moreover, the antioxidant capacity of wild blueberries was $48 \%$ higher than that of cultivated blueberries.

Blueberry was firstly cultivated and planted in North America. However, this fruit is widespread nowadays. Blueberries are cultivated in more than 40 countries around the world, and more than 20 Blueberries species exist. Ukraine holds 16th position in the world list "Top blueberry growing countries in the world" with more than 2000 tons of blueberries produced annually.

Modern studies encompass plantings of blueberries in a great diversity of environmental conditions to produce the most profitable species. Ukrainian soil is suitable for plant normal development, which determines the economic feasibility of it growing in Ukraine for domestic market and export needs.

Therefore, the relevance of the work is to gather available information that displays correlation of antioxidant properties on particular part and species of the plant. Consequently, with growing capabilities of blueberries production within the territory of Ukraine, it would be possible to beneficially use those thousands tones of produced berries. 
To determine the biologically active compounds in blueberries certain methods are used such as DPPH and ORAC method.

With the help of ORAC method antioxidant properties of blueberries sp. were investigated (Mainland and Tucker 2002). Nevertheless, the concentration of antioxidants may differ in respect to the part of the plant. Table 1 gives the clear understanding of the fact that skin of southern highbush blueberries contains double amount of antioxidants than those in the seeds [3].

Table 1

ORAC, phenolic and anthocyanin levels in different parts of southern highbush blueberries "Reveille" and "Bladen"

\begin{tabular}{|c|c|c|c|c|}
\hline Cultivar & Maturity stage & $\begin{array}{c}\text { ORAC }(\mu \mathrm{mol} \\
\mathrm{TE} / \mathrm{mg} \mathrm{FW})\end{array}$ & $\begin{array}{c}\text { Phenolics } \\
(\mathrm{mg} / \mathrm{g})\end{array}$ & $\begin{array}{c}\text { Anthocyanins } \\
(\mathrm{mg} / \mathrm{g})\end{array}$ \\
\hline Reveille & Whole berry & 16 & 2.9 & 1.0 \\
\cline { 2 - 5 } & Seeds & 28 & 5.6 & 1.4 \\
\cline { 2 - 5 } & Skin & 66 & 9.8 & 9.1 \\
\hline Bladen & Whole berry & 34 & 5.2 & 2.3 \\
\cline { 2 - 5 } & Seeds & 59 & 14.2 & 1.6 \\
\cline { 2 - 5 } & Skin & 166 & 27.4 & 12.7 \\
\hline
\end{tabular}

Moreover, antioxidant capacity may be affected by maturity of blueberries sp. Maturity may have significant effect on ORAC values. Mainly pre-ripe fruits contain the lowest amount of antioxidants (Table 2) [3]. Overripe rabbiteye blueberries showed increase in ORAC values by $10 \%$, respectively ripe rabbiteye blueberries did not reach those values. However, highbush blueberries have reverse statistics. From the ripe to the overripe stage the level of ORAC decreases (Mainland and Tucker 2002). 
ORAC, phenolic and anthocyanin levels in highbush ("Croatan", "Reveille", "Bladen") and rabbiteye ("Tifblu", "Powderblue") blueberries of three stages of maturity (pre-ripe $=$ slight red on scar; ripe $=$ full ripe; overripe = beginning to soften)

\begin{tabular}{|c|c|c|c|c|}
\hline Cultivar & Maturity stage & $\begin{array}{l}\text { ORAC ( } \mu \text { mol } \\
\text { TE/mg FW) }\end{array}$ & $\begin{array}{l}\text { Phenolics } \\
\text { (mg/g) }\end{array}$ & $\begin{array}{c}\text { Anthocyanins } \\
(\mathrm{mg} / \mathrm{g})\end{array}$ \\
\hline \multirow[t]{3}{*}{ Croatan } & Pre-ripe & 24 & 3.6 & 1.2 \\
\hline & Ripe & 26 & 3.6 & 1.6 \\
\hline & Overripe & 23 & 3.8 & 1.4 \\
\hline \multirow[t]{3}{*}{ Reveille } & Pre-ripe & 12 & 1.9 & 0.3 \\
\hline & Ripe & 16 & 2.6 & 0.7 \\
\hline & Overripe & 15 & 2.5 & 0.6 \\
\hline \multirow[t]{3}{*}{ Bladen } & Pre-ripe & 24 & 3.3 & 0.7 \\
\hline & Ripe & 43 & 5.2 & 1.9 \\
\hline & Overripe & 34 & 4.1 & 2.0 \\
\hline \multirow{3}{*}{$\begin{array}{l}\text { Average } \\
\text { highbush }\end{array}$} & Pre-ripe & 20 & 2.9 & 0.7 \\
\hline & Ripe & 28 & 3.8 & 1.4 \\
\hline & Overripe & 24 & 3.5 & 1.3 \\
\hline \multirow[t]{3}{*}{ Tifblue } & Pre-ripe & 8 & 1.2 & 0.2 \\
\hline & Ripe & 16 & 2.5 & 0.7 \\
\hline & Overripe & 21 & 3.2 & 0.9 \\
\hline \multirow[t]{3}{*}{ Powderblue } & Pre-ripe & 13 & 2.1 & 0.3 \\
\hline & Ripe & 21 & 3.4 & 1.0 \\
\hline & Overripe & 26 & 4.6 & 1.4 \\
\hline \multirow{3}{*}{$\begin{array}{l}\text { Average } \\
\text { rabbiteye }\end{array}$} & Pre-ripe & 11 & 1.7 & 0.3 \\
\hline & Ripe & 23 & 3.0 & 0.9 \\
\hline & Overripe & 25 & 3.9 & 1.2 \\
\hline
\end{tabular}


It should be mentioned, that highbush blueberry contain in average the highest amount of antioxidants accordingly to several studies. This berry is highly recommended to grow for commercial purposes.

The DPPH radical-scavenging curves clearly indicated that DPPH radicalscavenging activity for blackberry and blueberry increased significantly with extract concentrations over $0.4 \mathrm{mg} / \mathrm{ml}$, while for strawberry it increased more gradually. The three berries scavenged from $26.71 \%$ to $30.90 \%$ of DPPH radicals at low concentration $(0.08 \mathrm{mg} / \mathrm{ml})$ [7]. At $2.0 \mathrm{mg} / \mathrm{ml}$, blueberry and blackberry extracts could scavenge nearly all DPPH radicals (96.96\% and $95.37 \%$, respectively), and strawberry extract showed $58.32 \%$ DPPH radical-scavenging activity (Huang et al 2012).

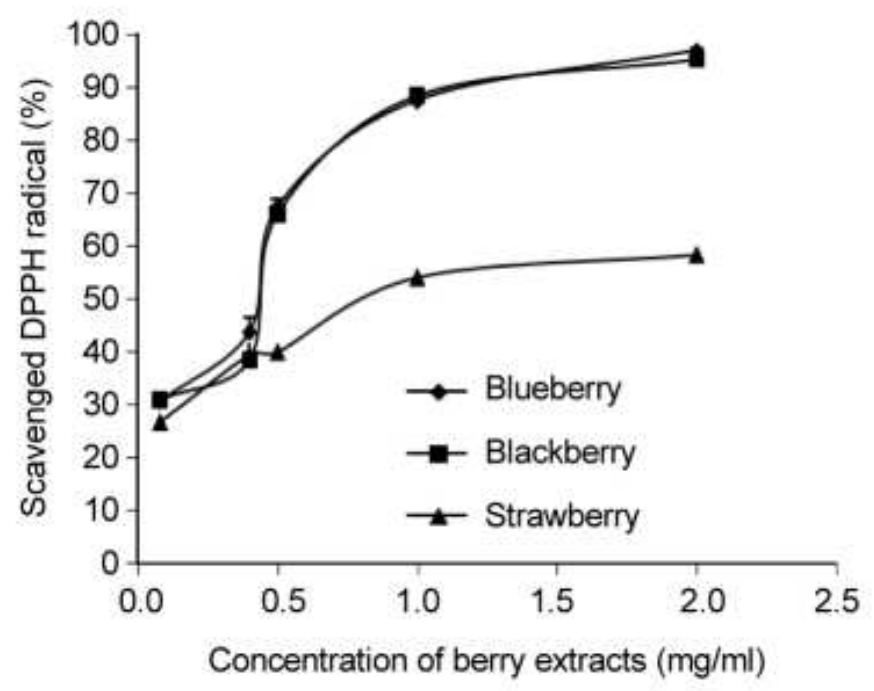

Fig. 1 DPPH radical-scavenging activities (determined for three berry extracts at different concentrations)

Figure 1 outlined above prove the presence of antioxidant properties in blueberries, it also suggested that blueberries among other berries has the highest percentage of DPPH radicals, which actually cause antioxidant properties.

Once, Vaccinium sp. are showing surge worldwide in production growth rates among other berry crops. Areas of commercial production have been ever expanding and nowadays it amount is substantially higher than under raspberries (app. $50 \%$ ). It 
should be mentioned that plantations sets out 3-4 years ago are now coming into bearing. Resulting the sharply grow of the supply of Vaccinium sp. in the nearest time.

In 2013 commercial plantings of blueberries counts to approximately 205 hectares, however in 2017 there were estimated 1500 hectares that were used for Vaccinium sp. production (Fig. 2).

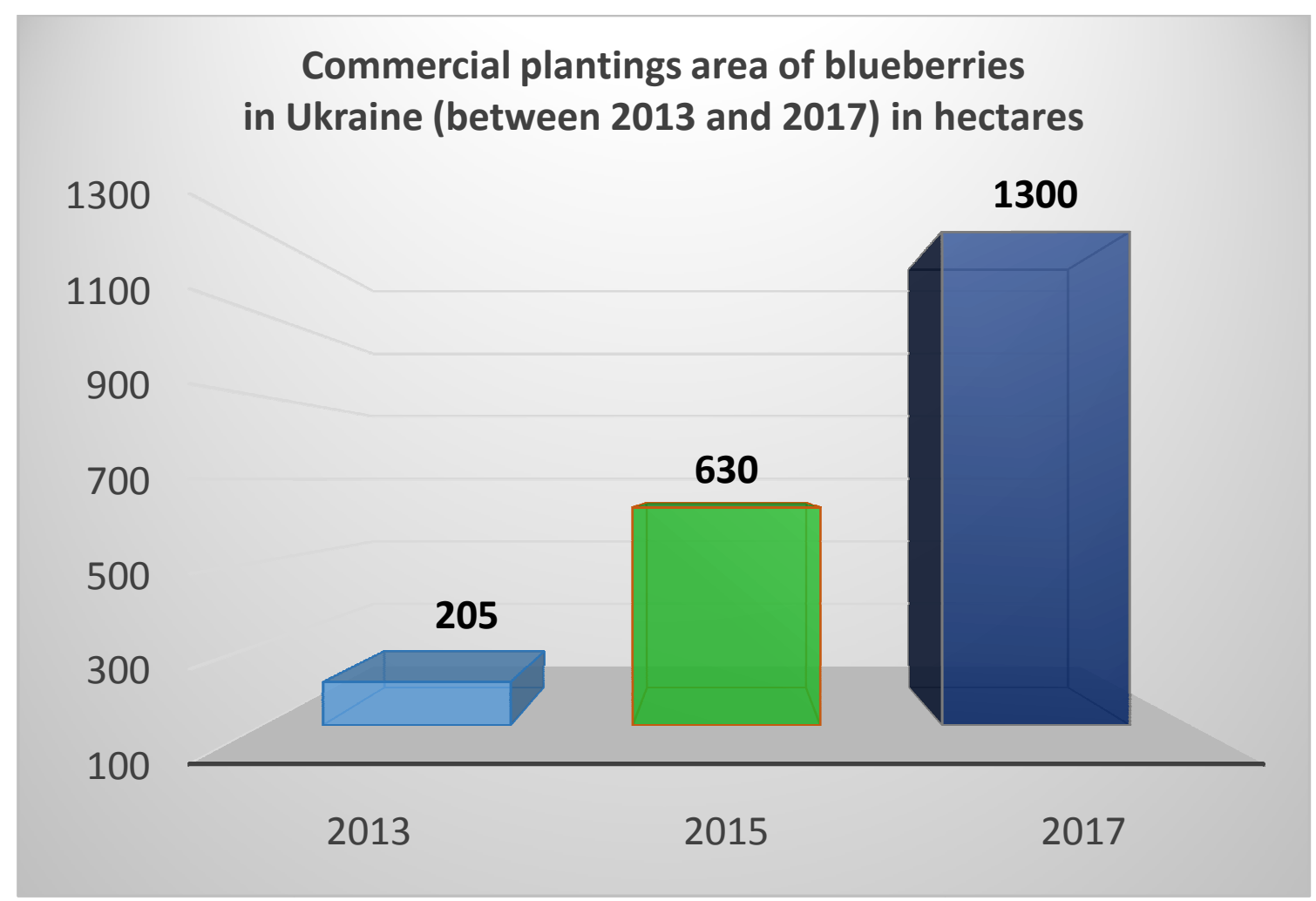

Fig. 2 Commercial plantings area of blueberries in Ukraine between 2013 and 2017

Increased attention is drawn to Ukrainian lands that have desirable conditions for growth and fruiting of those plants. It was counted almost 200 hectares of blueberries in Volyn region and more than 100 hectares in Kiev region. The leader position of blueberries production fields is devoted to Zhitomir region with the area of more than 400 hectares. This are due to proper climate conditions that influenced on the blueberries growth and reproduction [13]. The suitability of Ukrainian lands determines the economic feasibility of blueberry growing in Ukraine for domestic market and export needs. 
In should be mentioned that different factors influence blueberries production rates among the territory of Ukraine. Firstly, the possibility to export it in EU countries, where this type of berries is of great demand.

Secondly, the prices per $\mathrm{kg}$ in EU are ridiculously high, that ensure the possibility of it exporting, making this business profitable for national economic of Ukraine. The figure 3 below outline export of blueberries between 2013 and 2017. As general trend in 2017 export of blueberries reached the highest value among other years, ensuring the country position in the world list "Top blueberry growing countries in the world".

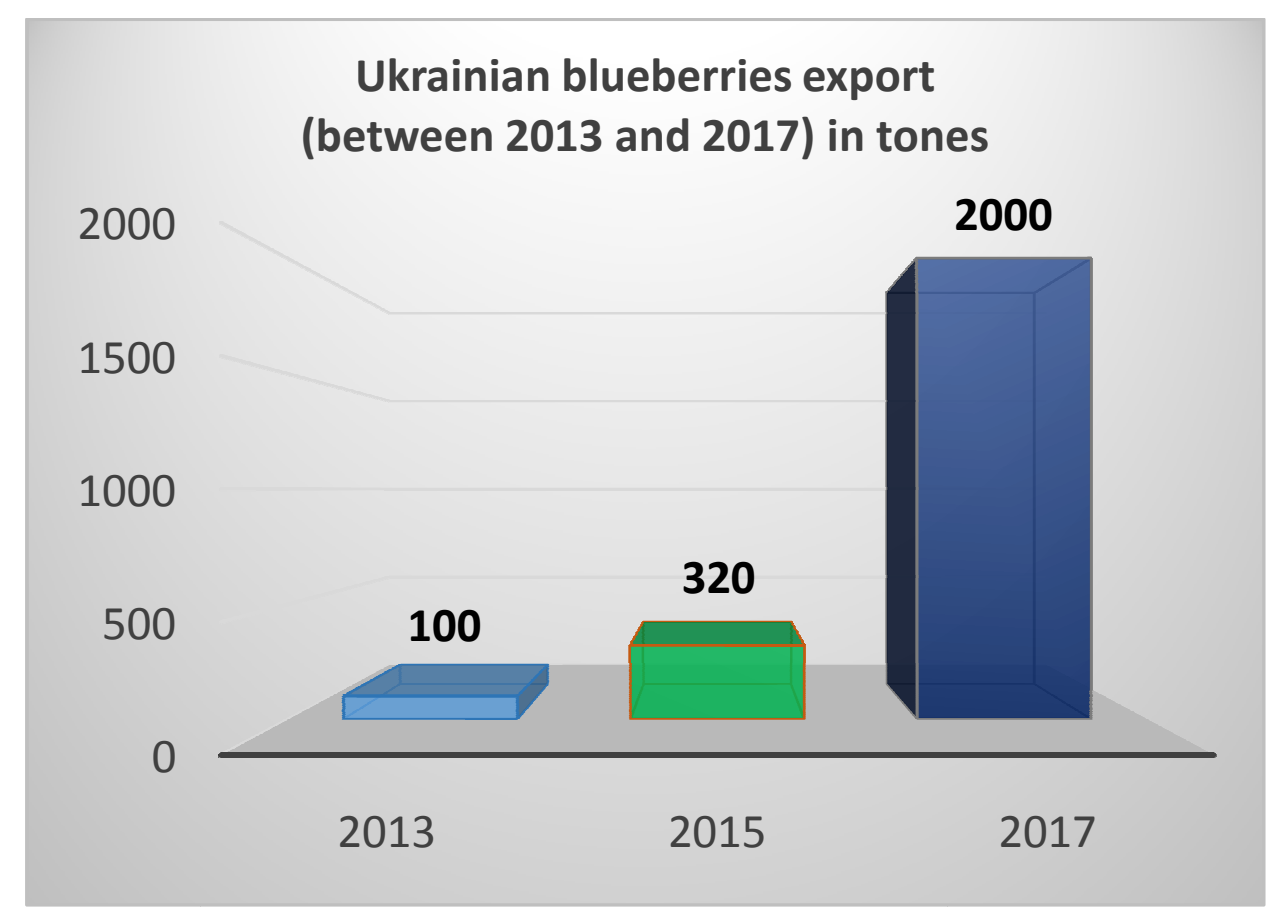

Fig. 3 Ukrainian blueberries export between 2013 and 2017

It can be suspected the brilliant development of the blueberries plantation. Nevertheless, high price does not build the appropriate market demand among Ukrainians. The supplied figure (Fig. 4) outlines the information of market share and volumes of blueberry market sales in 2017. Nowadays statistic does not show the great volume of blueberry market sales (less than $1 \%$ ), due to the fact, that price per $\mathrm{kg}$ of fresh blueberries is in ten times bigger than for the same quantity of strawberries. 


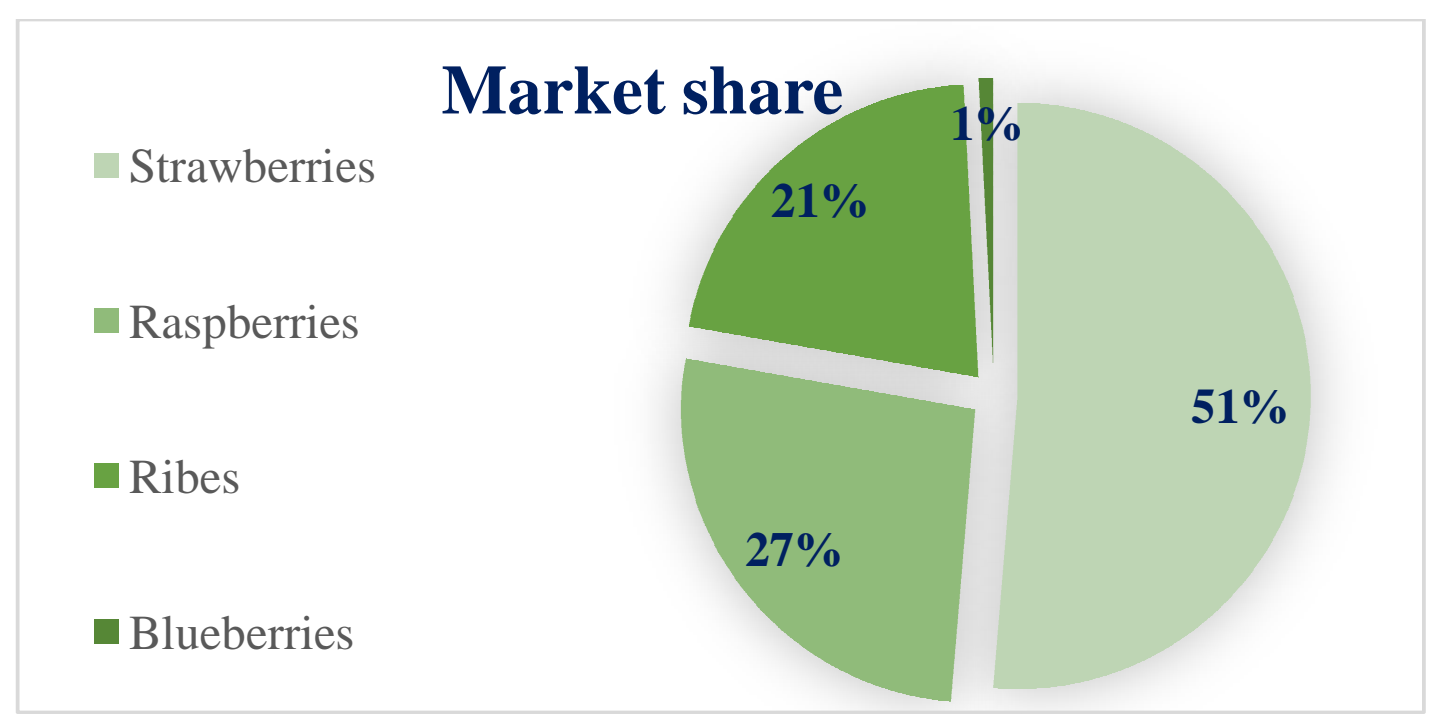

Fig. 4 Volume of blueberry market sales in Ukraine in 2017

\section{CONCLUSION}

For investigation of antioxidant properties of blueberries ORAC and DDPH methods are used. The DPPH radical-scavenging method identify the highst radicalscavenging activity for blueberry in correspondence to other berries. According to the studies, the highest antioxidant capacity was observed in the skin of ripe "Bladen" highbush blueberries. These results were obtained using ORAC method.

The economical profit of blueberries was investigated in terms of this work. It was suspected, that in recent few years there was observed increase in the quantity of commercial plantings area of blueberries. Additionally, export of this plant surge dramatically within the last four years reaching 2000 tons annually. However, blueberry is still expensive fruit on the domestic market, counting only $1 \%$ from total berries sales in 2017. However, till 2020 is expected surge in production of blueberries, their market sales will cross $5 \%$.

\section{REFERENCES}

1. Use of a Free Radical Method to Evaluate Antioxidant Activity / [BrandWilliams W., Cuvelier M. E., Berset C.] // LWT - Food Science and Technology. 1995. - № 28. - P. 25-30. 
2. Oxygen radical absorbing capacity, anthocyanin and phenolic content of highbush blueberries (Vaccinium corymbosum L.) during ripening and storage / Kalt W., Lawand C., Ryan D.A.J. et al. // Journal of the American Society for Horticultural Science. - 2003. - № 128. - P. 917-923.

3. Mainland C.M. Blueberry health information - some new, mostly review/ C.M. Mainland, J.W. Tucker// Acta Horticulturae. - 2002. - № 574. - P. 39-43.

4. Phenolic profile and antioxidant activity of highbush blueberry (Vaccinium corymbosum) during fruit maturation, ripening and storage/ Castrejon A.D.R., Eichholz I., Rohn S. et al. // Food Chemistry. - 2008. - № 109. - P. 564-572.

5. Free radical scavenging activities measured by electron spin resonance spectroscopy and B16 cell antiproliferative behaviors of seven plants / Calliste C.A., Trouillas P., Allais D.P. et al. // Food Chemistry. - 2001. - № 49. - P. 3321-3332.

6. Oxygen radical absorbing capacity of anthocyanins / Wang H., Cao G. et al. // J. Agric. Food Chem. - 1997. - № 45. - P. 304-309.

7. Survey of antioxidant capacity and phenolic composition of blueberry, blackberry, and strawberry in Nanjing / Huang W.-Y., Zhang H.-C., Liu W.-X. et al. // Journal of Zhejiang University SCIENCE B. - 2012. - № 2. - P. 94-102.

8. Hancock J.F. Blueberries/ J.B. Retamales, J.F. Hancock. - London, UK: CABI, 2012. - 323 p.

9. Phenolic compounds and antioxidant activity of blueberry cultivars grown in Brazil / Rodrigues E., Poerner N., Rockenbach I. et al. // Ciência e Tecnologia de Alimentos. - 2011. - № 31. - P. 911-917.

10. BMG LABTECH [Electronic resource]. - 2014. - Access mode: https://www.bmglabtech.com/fileadmin/06_Support/Download_Documents/Applicati on_Notes/AN267.pdf. - ORAC

11. Development and validation of oxygen radical absorbance capacity assay for lipophilic antioxidants using randomly methylated $\beta$-cyclodextrin as the solubility enhancer / Huang D., Ou B., Hampsch-Woodill M. et al. // Journal of Agricultural Food Chemistry. - 2002. - № 50. - P. 1815-1821. 
12. High-throughput Assay of Oxygen Radical Absorbance Capacity (ORAC) Using a Multichannel Liquid Handling System Coupled with a Microplate Fluorescence Reader in 96-Well Format / Huang D., Ou B., Hampsch-Woodill M. et al. // Journal of Agricultural Food Chemistry. - 2002. - № 50. - P. 4437-4444.

13. ProConsulting [Electronic resource]. - 2017. - Access mode: - https://proconsulting.ua/ua/pressroom/est-potencial-biznes-plan-predpriyatiya-povyrashivaniyu-golubiki

\section{АНТИОКСИДАНТНІ ВЛАСТИВОСТІ РІЗНИХ СОРТІВ ЛОХИНИ}

\section{Б.-О. О. ГРИВНАК, М.М. БАРАНОВСЬКИЙ}

Національний авіаційний університет, м. Київ

B даний час антиоксидантні властивості лохини широко використовуються в медицині як для виробництва лікарських препаратів так $i$ як добавки до косметичної продукиії. Цей фрукт містять у складі фенольні сполуки, які забезпечують антиоксидантні властивості. На території Украӥни збільшується кількість плантації чорниџі, тому особливо актуальним $\epsilon$ вивчення антиоксидантних властивостей різних видів лохини. Для рекомендаиій щэодо виробниџтва комериійних сортів лохини необхідно визначити вміст біологічно активних речовин та оцінити їхню антиоксидантну активність потенційно корисних частин рослини.

Ключові слова: лохина, антиоксидант, флавоноїди, антоиіани, поліфеноли, економічна доцільність, ОRАC, DPPH, вільні радикали. 


\title{
АНТИОКСИДАНТНЫЕ СВОЙСТВА РАЗЛИЧНЫХ СОРТОВ ГОЛУБИКИ
}

\author{
Б.-О. О. ГРИВНАК, М.М. БАРАНОВСБКИЙ
}

Национальный авиационный университет, г. Киев

В настоящее время антиоксидантные свойства голубики широко используются в медицине как для производства лекарственных препаратов так и в качестве добавки к косметической продукции. Этот фрукт содержит в составе фенольные соединения, которые обеспечивают антиоксидантные свойства. На территории Украины увеличивается количество плантации голубики, поэтому особенно актуальным является изучение антиоксидантных свойств различных видов голубики. Для рекомендащий по производству коммерческих сортов голубики необходимо определить содержание биологически активных веществ и оценить их антиоксидантной активность потенциально полезных частей растения.

Ключевые слова: голубика, антиоксидант, флавоноиды, антоцианы, полифеноль, экономическая иелесообразность, ORAC, DPPH, свободные радикалье. 